\title{
Osteomalacia in Paget's disease treated with short term, high dose sodium etidronate
}

\begin{abstract}
Eleven patients with Paget's disease treated with sodium etidronate $20 \mathrm{mg} / \mathrm{kg} /$ day for two and four weeks showed significant reductions in plasma alkaline phosphatase activity and urinary hydroxyproline excretion, both of which are biochemical markers of bone turnover. After four weeks of treatment, however, histological examination of iliac crest biopsy samples showed that despite a rapid reduction in bone resorption there was an appreciable mineralisation defect; even after only two weeks' treatment the abnormalities in bone formation persisted for up to 10 weeks.
\end{abstract}

The adverse effects of sodium etidronate on mineralisation cannot be dissociated from its beneficial effect on resorption even when it is given for short periods.

\section{Introduction}

When sodium etidronate (EHDP) was first used in Paget's disease doses of $10-20 \mathrm{mg} / \mathrm{kg} /$ day for six months reduced the plasma alkaline phosphatase activity and urinary hydroxyproline excretion, both of which are biochemical markers of bone turnover. ${ }^{12}$ This regimen, however, resulted in a mineralisation defect and an increased prevalence of fractures, particularly with the higher doses, ${ }^{134}$ indicating that high doses for long periods must be used with caution. Reducing the dose does not circumvent these problems as it results not only in decreased efficacy ${ }^{2}$ but also in abnormalities of mineralisation, described as "focal osteomalacia."

Because of the satisfactory biochemical response obtained within three months of treatment with sodium etidronate a dose of $20 \mathrm{mg} / \mathrm{kg} /$ day for shorter periods has been suggested. ${ }^{6}$ We aimed to determine the effect of such high doses on biochemistry and bone histology when given for short periods (two and four weeks).

\section{Methods}

We studied 11 patients (six men, five women) aged 48-74 with symptomatic Paget's disease. All had radiographic evidence of the disease and raised plasma alkaline phosphatase activity. Three patients had previously been treated with calcitonin and three with sodium etidronate $5 \mathrm{mg} / \mathrm{kg} /$ day for up to six months. All treatment was stopped one year before the study, except in one patient, who stopped taking sodium etidronate three months before the study.

The patients were divided into two groups. One comprised six patients (four men, two women) who took sodium etidronate $20 \mathrm{mg} / \mathrm{kg} /$ day for one month and underwent bone biopsy before and at the end of treatment. The second group comprised five patients (two men, three women) who took sodium etidronate $20 \mathrm{mg} / \mathrm{kg} /$ day for two weeks and underwent a single bone biopsy either at the end of treatment or 10-16 weeks later.

Patients took the sodium etidronate each morning at 7 am after fasting overnight; they then fasted until $9 \mathrm{am}$. Plasma and urine were collected after an overnight fast before treatment, at the end of treatment, and one month,

\footnotetext{
Medical Research Council Mineral Metabolism Unit, General Infirmary, Leeds LS1 3EX

CHARLES J GIBBS, MRCP, registrar

JEAN E AARON, PHD, senior research officer

MUNRO PEACOCK, FRCP, acting director and consultant physician

Correspondence to: Dr Peacock.
}

three months, and six months after the start of treatment. Plasma calcium and phosphate concentrations and alkaline phosphatase activity were measured with a Technicon SMAC autoanalyser. Urinary hydroxyproline excretion was measured by colorimetry after resin catalysed hydrolysis ${ }^{7}$ and urinary creatinine by autoanalyser. Plasma $1,25(\mathrm{OH})_{2}$ vitamin D was measured by specific radioimmunoassay after initial extraction and separation of lipids by high pressure liquid chromatography ${ }^{8}$ This method has an intra-assay coefficient of variation of $7 \cdot 1 \%$ at $78 \mathrm{pmol} / 1(31 \mathrm{pg} / \mathrm{ml})$.

Biopsy of the transiliac crest was performed under local anaesthetic with an $8 \mathrm{~mm}$ Bordier trephine 10-14 days after the administration of demeclocycline ( $150 \mathrm{mg}$ four times a day for three days). Specimens were immersed in $1 \%$ xylenol orange in $10 \%$ buffered formalin, embedded in methylmethacrylate, and sectioned on a Jung $\mathrm{K}$ heavy duty microtome; the rate of trabecular calcification was estimated using contrasting fluorochromes in vitro. ${ }^{9}$ Sections were stained with Goldner's stain or with $1 \%$ toluidine blue stain ( $\mathrm{pH} \mathrm{3.5)} \mathrm{for} \mathrm{quantitative} \mathrm{histomorphometry} \mathrm{of} \mathrm{bone} \mathrm{to} \mathrm{obtain} \mathrm{values}$ for seam width, forming and resorbing surfaces, and calcification fronts. ${ }^{10}$

Alkaline phosphatase activity and hydroxyproline excretion were transformed logarithmically for analysis. Student's $t$ test was applied to all variables.

\section{Results}

Table I shows the biochemical values in the six patients given four weeks' treatment. Plasma phosphate concentration rose during treatment but had fallen at three and six months. Plasma alkaline phosphatase activity had fallen at the end of treatment, but the maximum effect was noted at three months. The ratio of urinary hydroxyproline to creatinine had fallen at the end of treatment but had started to rise at three months. Table II shows the results of histological examination of bone in the six patients. The proportion of resorbing surfaces, the proportion of forming surfaces bearing a calcification front, and the trabecular calcification rate fell while the proportion of forming surfaces and the seam width increased.

Tables III and IV show the findings in the five patients treated for two weeks. Plasma phosphate concentration increased during treatment but had returned to the pretreatment value by three months. Plasma alkaline phosphatase activity did not decrease until one month after the start of treatment and then continued to fall. The ratio of urinary hydroxyproline to creatinine fell with treatment. Histological examination of a bone biopsy specimen taken immediately after treatment in one case (case 7) showed a mineralisation defect (table IV); biopsy specimens obtained after 10 weeks in three cases did not show such a defect, although bone resorption was increased in two (cases 8 and 9 ).

\section{Discussion}

Sodium etidronate $20 \mathrm{mg} / \mathrm{kg} /$ day produces a clinical, biochemical, and histological response in patients with Paget's disease when given for six months. ${ }^{12}$ Our study showed that it also produces a beneficial response when given for two to four weeks. The biochemical markers of bone resorption, plasma alkaline phosphatase activity and the urinary hydroxyproline:creatinine ratio, decreased during the course of treatment and remained suppressed for three months. The change in plasma alkaline phosphatase activity lagged behind that in the hydroxyproline:creatinine ratio, with a maximal response at three months. The plasma phosphate concentration increased after two weeks' treatment owing to increased tubular reabsorption of phosphate, ${ }^{11}$ a reliable signal that the drug had been absorbed. The bone histology in the patients from whom biopsy specimens were taken on two occasions was consistent with the biochemical response, showing a fall in resorbing surfaces after treatment for one month.

The biopsy specimens taken after one month's treatment showed that a pronounced mineralisation defect had developed. Histo- 
morphometry showed an increase in forming surfaces, a reduction in the extent of surfaces bearing a calcification front, and a reduced rate of trabecular calcification. Osteomalacia, as defined by both an increase in osteoid surfaces and a reduction in calcification fronts, was present in five out of six patients. Previous studies after three to six months' treatment showed similar histological changes. ${ }^{23}$ Even after only two weeks' treatment we found evidence of a mineralisation defect, which confirms recent findings. ${ }^{12}$ In our study biopsy more than 10 weeks after two weeks' treatment showed no impairment of bone formation. Thus the mineralisation defect was probably not permanent and resolved spontaneously, as others have shown. ${ }^{12}$ One study showed that the mineralisation defect persisted for up to nine months after the end of treatment, ${ }^{1}$ but treatment was for 29 weeks, suggesting that persistence of the defect depends on the dose.

Whether repeated short courses of sodium etidronate $20 \mathrm{mg} / \mathrm{kg} /$ day produces less impairment of mineralisation than protracted treatment remains to be established. One study showed that symptoms and biochemical variables were controlled with sodium etidronate $20 \mathrm{mg} / \mathrm{kg} /$ day for one month out of every four over two years. ${ }^{13}$ Bone histology, however, was not examined. Another study suggested that the biochemical activity of the disease remains

TABLE I-Plasma and urine biochemistry before and after treatment with sodium etidronate $20 \mathrm{mg} / \mathrm{kg} /$ day for one month in six patients. Values are means (SEM)

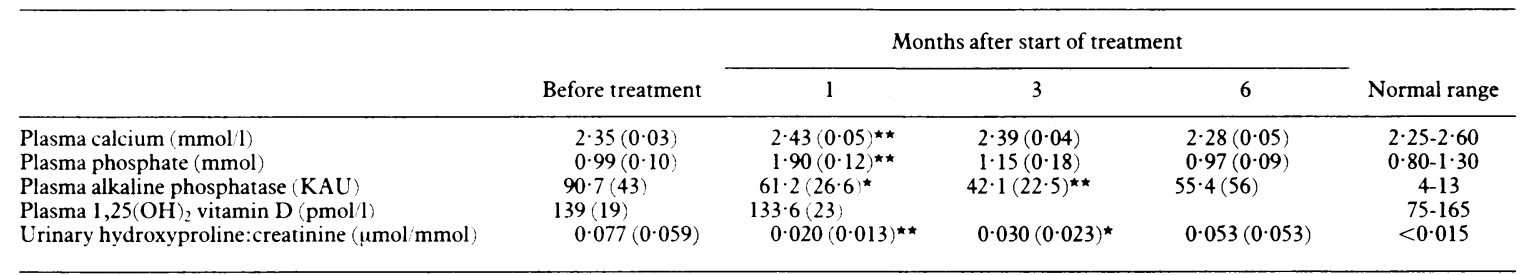

${ }^{\star} \mathrm{p}<0.05 .{ }^{\star \star} \mathrm{p}<0.01$.

Conversion: SI to traditional units—Calcium: $1 \mathrm{mmol} / \approx 4 \mathrm{mg} / 100 \mathrm{ml}$. Phosphate: $1 \mathrm{mmol} / \approx=3 \cdot 1 \mathrm{mg} / 100 \mathrm{ml} .1,25(\mathrm{OH}), \mathrm{Vitamin} \mathrm{D}: 1 \mathrm{pmol} / \mathrm{l} \approx 0 \cdot 4 \mathrm{pg} / \mathrm{ml}$. Hydroxyproline:creatinine: $1 \mu \mathrm{mol} / \mathrm{mmol} \approx 1 \cdot 2 \mathrm{mg} \mathrm{g}$.

TABLE II-Bone histology before and immediately after treatment with sodium etidronate $20 \mathrm{mg} / \mathrm{kg} /$ day for one month in six patients

\begin{tabular}{|c|c|c|c|c|c|c|}
\hline Case No & $\begin{array}{c}\text { Time of } \\
\text { assessment }\end{array}$ & $\begin{array}{c}\% \text { Of } \\
\text { resorbing surfaces }\end{array}$ & $\begin{array}{c}\% \text { Of } \\
\text { forming surfaces }\end{array}$ & $\begin{array}{l}\% \text { Of forming surfaces } \\
\text { bearing calcification front }\end{array}$ & $\begin{array}{l}\text { Rate of trabecular calcification } \\
(\mu \mathrm{m} / \text { day })\end{array}$ & $\begin{array}{l}\text { Width of seam } \\
(\mu \mathrm{m})\end{array}$ \\
\hline 1 & $\left\{\begin{array}{l}\text { Before } \\
\text { After }\end{array}\right.$ & $\begin{array}{l}37 \\
11\end{array}$ & $\begin{array}{l}27 \\
57\end{array}$ & $\begin{array}{l}91 \\
35\end{array}$ & $\begin{array}{l}1 \cdot 73 \\
0.00\end{array}$ & $\begin{array}{l}12 \cdot 3 \\
32 \cdot 7\end{array}$ \\
\hline 2 & $\left\{\begin{array}{l}\text { Before } \\
\text { After }\end{array}\right.$ & $\begin{array}{r}15 \\
9\end{array}$ & $\begin{array}{l}16 \\
83\end{array}$ & $\begin{array}{l}70 \\
33\end{array}$ & $\begin{array}{l}0.64 \\
0.00\end{array}$ & $\begin{array}{l}23 \cdot 1 \\
52 \cdot 7\end{array}$ \\
\hline 3 & $\left\{\begin{array}{l}\text { Before } \\
\text { After }\end{array}\right.$ & $\begin{array}{l}11 \\
20\end{array}$ & $\begin{array}{l}14 \\
37\end{array}$ & $\begin{array}{l}82 \\
47\end{array}$ & $\begin{array}{l}0.80 \\
0.66\end{array}$ & $\begin{array}{r}8 \cdot 2 \\
33 \cdot 0\end{array}$ \\
\hline 4 & $\left\{\begin{array}{l}\text { Before } \\
\text { After }\end{array}\right.$ & $\begin{array}{l}4 \\
6\end{array}$ & $\begin{array}{l}9 \\
5\end{array}$ & $\begin{array}{l}69 \\
44\end{array}$ & $\begin{array}{l}\text { Not labelled } \\
0.00\end{array}$ & $\begin{array}{l}17 \cdot 7 \\
23 \cdot 1\end{array}$ \\
\hline 5 & $\left\{\begin{array}{l}\text { Before } \\
\text { After }\end{array}\right.$ & $\begin{array}{l}56 \\
23\end{array}$ & $\begin{array}{l}38 \\
52\end{array}$ & $\begin{array}{l}59 \\
25\end{array}$ & $\begin{array}{l}1 \cdot 24 \\
0 \cdot 02\end{array}$ & $\begin{array}{l}20 \cdot 0 \\
49 \cdot 8\end{array}$ \\
\hline 6 & $\left\{\begin{array}{l}\text { Before } \\
\text { After }\end{array}\right.$ & $\begin{array}{l}41 \\
30\end{array}$ & $\begin{array}{l}38 \\
52\end{array}$ & $\begin{array}{r}100 \\
28\end{array}$ & $\begin{array}{l}1 \cdot 28 \\
0.56\end{array}$ & $\begin{array}{l}12 \cdot 9 \\
50 \cdot 3\end{array}$ \\
\hline $\begin{array}{l}\text { Mean (SEM) } \\
\text { Normal range }\end{array}$ & $\left\{\begin{array}{l}\text { Before } \\
\text { After }\end{array}\right.$ & $\begin{array}{l}27(8) \\
17(4) \\
<12\end{array}$ & $\begin{array}{l}24(5) \\
52(11)^{\star} \\
<24\end{array}$ & $\begin{array}{l}79(6) \\
35(4)^{\star \star} \\
60-100\end{array}$ & $\begin{array}{c}1 \cdot 14(0 \cdot 19) \\
0 \cdot 21(0 \cdot 13)^{\star \star} \\
0 \cdot 10-0 \cdot 90\end{array}$ & $\begin{array}{c}15 \cdot 7(2 \cdot 3) \\
40 \cdot 3(5 \cdot 0)^{\star \star} \\
5-12\end{array}$ \\
\hline
\end{tabular}

${ }^{\star} \mathrm{p}<0.05 .{ }^{\star \star} \mathrm{p}<0.01$.

TABLE III-Plasma and urine biochemistry before and after treatment with sodium etidronate $20 \mathrm{mg} / \mathrm{kg} /$ day for two weeks in five patients. Values are means (SEM)

\begin{tabular}{|c|c|c|c|c|c|}
\hline \multirow{2}{*}{. } & \multirow[b]{2}{*}{$\begin{array}{l}\text { Before treatment } \\
\qquad(n=5)\end{array}$} & \multicolumn{4}{|c|}{ Time after start of treatment } \\
\hline & & $\begin{array}{c}2 \text { Weeks } \\
(n=4)\end{array}$ & 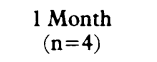 & $\begin{array}{l}3 \text { Months } \\
(n=5)\end{array}$ & 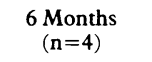 \\
\hline $\begin{array}{l}\text { Plasma calcium }(\mathrm{mmol} / \mathrm{l}) \\
\text { Plasma phosphate }(\mathrm{mmol} / \mathrm{l}) \\
\text { Plasma alkaline phosphatase }(\mathrm{KAU}) \\
\text { Urinary hydroxyproline:creatinine ratio }(\mu \mathrm{mol} / \mathrm{mol})\end{array}$ & $\begin{array}{l}2 \cdot 38(0 \cdot 04) \\
1 \cdot 02(0 \cdot 07) \\
46 \cdot 3(24 \cdot 1) \\
0.052(0 \cdot 025)\end{array}$ & $\begin{array}{l}2.41(0.06) \\
1.75(0 \cdot 14)^{\star} \\
53 \cdot 3(40 \cdot 4) \\
0.018(0.009)^{\star}\end{array}$ & $\begin{array}{l}2 \cdot 36(0 \cdot 06) \\
1 \cdot 30(0 \cdot 08) \\
35 \cdot 1(18 \cdot 4)^{\star} \\
0 \cdot 020(0 \cdot 030)\end{array}$ & $\begin{array}{l}2 \cdot 26(0 \cdot 04) \\
0 \cdot 95(0 \cdot 12) \\
20 \cdot 4(7 \cdot 2) \\
0 \cdot 028(0 \cdot 029)\end{array}$ & $\begin{array}{l}2.36(0.02) \\
0.88(0.11) \\
16.0(4 \cdot 0) \\
0.013(0.008)\end{array}$ \\
\hline
\end{tabular}

${ }^{\star} \mathrm{p}<0.05$

Conversion: SI to traditional units_Calcium: $1 \mathrm{mmol} / \mathrm{l} \approx 4 \mathrm{mg} / 100 \mathrm{ml}$. Phosphate: $1 \mathrm{mmol} / \approx \approx 3 \cdot 1 \mathrm{mg} / 100 \mathrm{ml}$. Hydroxyproline:creatinine: $1 \mu \mathrm{mol} / \mathrm{mmol} \approx 1 \cdot 2 \mathrm{mg} / \mathrm{g}$.

TABLE IV-Bone histology after treatment with sodium etidronate $20 \mathrm{mg} / \mathrm{kg} /$ day for two weeks in five patients

\begin{tabular}{|c|c|c|c|c|c|c|}
\hline Case No & $\begin{array}{l}\text { Time after treatment } \\
\text { (weeks) }\end{array}$ & $\begin{array}{c}\% \text { Of } \\
\text { resorbing surfaces }\end{array}$ & $\begin{array}{c}\% \text { Of } \\
\text { forming surfaces }\end{array}$ & $\begin{array}{l}\% \text { Of forming surfaces } \\
\text { bearing calcification front }\end{array}$ & $\begin{array}{l}\text { Rate of trabecular calcification } \\
(\mu \mathrm{m} / \text { day })\end{array}$ & $\begin{array}{l}\text { Width of seam } \\
(\mu \mathrm{m})\end{array}$ \\
\hline 7 & Immediately & 9 & 9 & 44 & $0 \cdot 30$ & $23 \cdot 5$ \\
\hline 8 & 10 & 23 & 3 & 61 & 0.81 & $18 \cdot 6$ \\
\hline 9 & 11 & 12 & 5 & 69 & 1.05 & 5.0 \\
\hline 10 & 13 & 8 & 3 & 75 & 1.02 & $6 \cdot 7$ \\
\hline 11 & 16 & 9 & 1 & 87 & 0.84 & $6 \cdot 1$ \\
\hline
\end{tabular}


suppressed after only one month's treatment. ${ }^{12} \mathrm{We}$, however, found that the inhibition of bone resorption is temporary and that control of the disease needs repeated courses of treatment.

The precise mechanism causing the mineralisation defect is not known but was unrelated to changes in $1,25(\mathrm{OH})_{2}$ vitamin $\mathrm{D}$ in this study. Possible side effects of sodium etidronate include interference with alkaline phosphatase activity, reduced synthesis of proteoglycans, and a toxic effect on bone cells. ${ }^{14}$

In conclusion, sodium etidronate $20 \mathrm{mg} / \mathrm{kg} /$ day results in a biochemical improvement in Paget's disease when given for as short a period as two to four weeks, but it produces a mineralisation defect and the effect on bone resorption is not permanent. Although the defect in mineralisation spontaneously corrects when treatment is stopped we doubt whether any manipulation of the dose or duration of treatment can dissociate the drug's beneficial effects on resorption from its adverse effects on mineralisation. It is not, therefore, ideal for long term management of patients with Paget's disease.

\author{
References \\ 1 Smith R, Russell RGG, Bishop MC, Woods CG, Bishop M. Paget's disease of bone. Q J Med \\ 1973;42:235-56
}

2 Russell RGG, Smith R, Preston C, Walton RJ, Woods CG. Diphosphonates in Paget's disease. Lancet 1974; i:894-8.

3 Khairi MRA, Meunier P, Edouard C, et al. Quantitative bone histology in Paget's disease of bone: influence of sodium etidronate (EHDP) therapy. Calcified Tissue Research 1977;22(suppl): 355-8.

4 Khairi MRA, Altman MD, DeRosa GP, Zimmerman J, Schenk RK, Johnston CC. Sodium etidronate in the treatment of Paget's disease of bone. Ann Intern Med 1977;87:656-63.

5 Boyce BF, Smith L, Fogelman I, Johnston E, Ralston S, Boyce IT. Focal osteomalacia due to lowdose diphosphonate therapy in Paget's disease. Lancet 1984; ;:821-4.

6 Kanis JA, Evanson JM, Russell RGG. Paget's disease of bone: diagnosis and management. Metab Bone Dis Relat Res 1981;3:219-30.

7 Hodgkinson $A$, Thompson $T$. Measurement of the fasting urinary hydroxyproline:creatinine ratio in normal adults and its variation with age and sex. F Clin Pathol 1982;35:807-11.
ing

8 Taylor GA, Peacock M, Pelc B, Brown W, Holmes A. Purification of plasma vitamin D metabolites for radioimmunoassay. Clinica Chimica Acta 1980;108:239-46.

9 Aaron JE, Makins NB, Francis RM, Peacock M. Staining of the calcification front in human bone, using contrasting fluorochromes in vitro. F Histochem Cytochem 1984;32:1251-61.

10 Aaron J. Histological methods. In: Nordin BEC, ed. Calcium phosphate and magnesium metabolism. Edinburgh: Churchill Livingstone, 1976:564-8.

11 Walton RJ, Russell RGG, Smith R. Changes in renal and extrarenal handling of phosphate induced by sodium etidronate (EHDP) in man. Clinical Science and Molecular Medicine 1975;49:45-56.

12 Preston CJ, Yates AJP, Beneton MNC, et al. Effective short term treatment of Paget's disease with oral etidronate. Br Med f 1986;292:79-80.

13 Siris ES, Canfield RE, Jacobs TP, Stoddard KE, Spector PJ. Clinical and biochemical effects of EHDP in Paget's disease of bone: patterns of response to initial treatment and to long-term EHDP in Paget's disease of bone: patterns of re
therapy. Metab Bone Dis Relat Res 1981;3:301-8.

14 Plasmans CMT, Jap PHK, Kuigars W, Stoof TJJH. Influence of a diphosphonate on the cellular aspect of young bone tissue. Calcif Tissue Int 1980;32:247-56.

Accepted 4 March 1986

\title{
Deficiency of thiosulphate sulphurtransferase (rhodanese) in Leber's hereditary optic neuropathy
}

\author{
C J M POOLE, P R N KIND
}

\begin{abstract}
Leber's hereditary optic neuropathy is a rare cause of progressive visual failure. Its cause is unknown, but one hypothesis is that patients have a defect in the detoxication of cyanide. One of the enzymes used in this detoxication is thiosulphate sulphurtransferase (rhodanese). The activity of this enzyme was measured in the rectal mucosa of a group of subjects with Leber's hereditary optic neuropathy, and it was found to be considerably reduced compared with that in a group of controls $(p<0.001)$. This finding supports the hypothesis of an inborn error of cyanide detoxication in this condition.
\end{abstract}

\section{Introduction}

In 1965 Wilson showed that plasma and urinary thiocyanate concentrations were lower in a group of smokers with Leber's hereditary optic neuropathy than in a control group without this neuropathy. ${ }^{1}$ This and the finding of raised plasma cyanocobalamin concentrations in these patients ${ }^{2}$ led to the hypothesis that there is an inborn error in cyanide detoxication in patients with Leber's hereditary optic neuropathy. ${ }^{3}$ Another hypothesis is that Leber's

\footnotetext{
Departments of Neurology, Medical Ophthalmology, and Chemical Pathology, St Thomas's Hospital, London SE1 7EH

C J M POOLE, MB, MRCP, neurology registrar

P R N KIND, PHD, FRCPATH, top grade biochemist

Correspondence to: Dr C J M Poole, Medical Unit, Westminster Hospital, London SW1P 2AP.
}

hereditary optic neuropathy is a hereditary vascular neuroretinopathy. ${ }^{4}$

The main detoxication route for cyanide is the enzymic transfer of sulphur from thiosulphate (or mercaptopyruvate) to cyanide to form thiocyanate. Wilson found no difference in the activity of thiosulphate sulphurtransferase (rhodanese; EC 2.8.1.1) in liver samples taken at necropsy of two patients who had had Leber's hereditary optic neuropathy compared with samples from controls.' In 1981, however, Cagianut et al reported reduced activity of liver rhodanese in two patients with Leber's hereditary optic neuropathy compared with living and dead controls.

Rhodanese is an intramitochondrial enzyme and therefore may be found in most tissues; it occurs in large quantities in the liver and kidneys. For ethical and practical purposes rectal mucosa was chosen as the source of specimens for our enzyme assays. We compared the activity of rectal mucosa rhodanese in subjects with Leber's hereditary optic neuropathy with that in control subjects. In addition, rhodanese activity was measured in liver and rectal mucosa obtained at necropsy from controls.

\section{Patients and methods}

Ten white men with Leber's hereditary optic neuropathy from nine different families living in southern England were studied. All had optic atrophy that was inherited matroclinically and fulfilled the criteria of the diagnosis of Leber's hereditary optic neuropathy described by Lundsgaard ${ }^{6}$ -namely, a predominantly male affection with acute or subacute bilateral visual loss with central scotomas. At least one subject on the maternal side of each pedigree had been similarly affected. Control specimens were obtained from 12 white patients (seven men, five women) undergoing investigations for various bowel disorders such as carcinoma, colitis, and idiopathic diarrhoea ("diseased" controls) and from 20 white patients ( 17 men, three women) undergoing routine colonoscopy for colonic polyps ("healthy" controls). Three doctor volunteers also acted as "healthy" controls. Rectal 